\title{
The cost-effectiveness of alemtuzumab in the management of relapse-remitting multiple sclerosis in Italy
}

Global \& Regional Health Technology

Assessment

Volume 2019: 1-13

(C) The Author(s) 2019

Article reuse guidelines: sagepub.com/journals-permissions DOI: | 0.1 | 77/22842403| 9838524 journals.sagepub.com/home/grh

(3)SAGE

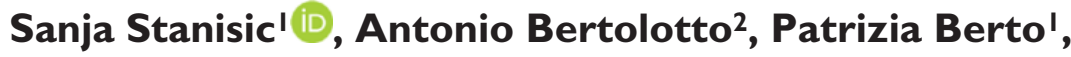 \\ Paolo Di Procolo ${ }^{3}$ and Julia Morawski ${ }^{4}$
}

\begin{abstract}
Multiple sclerosis is the most frequent cause of non-traumatic neurologic disability in young adults with over 3400 newly diagnosed cases annually in Italy. The research objective was to assess the cost-effectiveness of alemtuzumab in comparison with other disease-modifying therapies in the management of relapsing-remitting multiple sclerosis, from a payer perspective in Italy. A Markov model was created to assess cost-effectiveness of alemtuzumab in comparison with subcutaneous IFN $\beta$ - Ia, natalizumab and fingolimod. Treatment effects were derived from a network meta-analysis. Economic input included cost of therapies, their administration and follow-up, cost of adverse events and cost of relapse. Data on health care resource utilization and their costs were retrieved from published sources. Cost-effectiveness was measured as incremental cost $(€, 2017)$ per quality-adjusted life year while the robustness of the results was demonstrated in sensitivity analyses. Over a lifetime horizon, alemtuzumab yielded more quality-adjusted life years and less costs compared to the other disease-modifying therapies in all base-case analyses. Treatment with alemtuzumab yielded an incremental quality-adjusted life years of I.62, I.03 and I.36 with savings of $€ 43$ I 2, €8I,562 and €54,067 versus IFN $\beta$-la, fingolimod and natalizumab, respectively. Results on the multiple cost-effectiveness acceptability curve showed alemtuzumab carries the highest likelihood of being below the accepted willingness-to-pay threshold (€40,000) compared to IFN $\beta$-Ia, natalizumab and fingolimod. Based on the current analysis, alemtuzumab is likely to be costeffective versus IFN $\beta$-Ia, natalizumab and fingolimod in the treatment of relapsing-remitting multiple sclerosis patients in Italy.
\end{abstract}

\section{Keywords}

Alemtuzumab, antibodies monoclonal humanized, cost-effectiveness, Italy, multiple sclerosis

Date received: I4 September 2018; accepted: 26 February 2019

\section{Introduction}

Multiple sclerosis (MS) is a chronic immune-mediated neurologic disease characterized by inflammation, demyelination and axon degeneration. ${ }^{1}$ MS is the most frequent cause of non-traumatic neurologic disability in young adults (primary onset between 20 and 40 years of age). MS has a heterogeneous clinical presentation and it is classified into four phenotypes based on the severity and frequency of relapse and disease evolution (i.e. progression): relapse-remitting MS (RRMS), primary progressive MS (PPMS), secondary progressive MS (SPMS) and progressive-relapsing MS (PRMS). Approximately $85 \%$ of patients present with RRMS at disease onset, and around two-thirds of them progress to SPMS. ${ }^{1}$

The MS population affects approximately 2.8 million individuals worldwide, ${ }^{2}$ with a reported female-to-male ratio

\footnotetext{
'Certara Italy, Milan, Italy

${ }^{2}$ AOU San Luigi Gonzaga, Turin, Italy

${ }^{3}$ Sanofi, Milan, Italy

${ }^{4}$ Sanofi, Cambridge, MA, USA

Corresponding author:

Sanja Stanisic, Certara Italy, Via GB Pirelli 27, 20124 Milan, Italy.

Email: sanja.stanisic@certara.com
} 
of 2:1. ${ }^{3}$ The estimated median prevalence in Europe is 100 190/100,000, affecting around 600,000 people. ${ }^{4}$ In Italy, there are approximately 114,000 people affected by MS with over 3400 new diagnoses each year, based on 2017 data from the Italian Association of Multiple Sclerosis (AISM). ${ }^{4}$

MS poses a significant socioeconomic burden associated with the cost of treatment, detriment in patients' work productivity and increased need for supportive care in the advanced stages of the disease. ${ }^{5}$ In the early years following diagnosis, the cost of pharmaceuticals constitutes the largest share of the total costs of MS (29\%-82\% of all costs), while in later years, costs associated with loss of productivity and informal care $(17 \%-67 \%)$ comprise the largest share of the expenditure. ${ }^{6}$ Total annual costs of MS in Europe are estimated to reach $€ 14.6$ billion. ${ }^{5}$ Several researchers have investigated costs associated with MS in Italy. ${ }^{7-10}$ The average cost of diagnosis is estimated to be $€ 1236 /$ patient and is due to hospital and day hospital admissions, and instrumental and laboratory investigations in the ambulatory setting. ${ }^{9}$ In patients with mild severity (Expanded Disability Status Scale (EDSS) 0-3.5), direct medical and rehabilitation costs were estimated at $€ 9949 /$ year/patient; these costs were derived through a cost of illness study by Berto et al. based on data from 8326 Italian MS patients. ${ }^{9}$ The pan-European study on Treatment Experience, Burden and Unmet Needs (TRIBUNE) found the mean per patient cost of MS management increases substantially to $€ 22,461 \quad(\mathrm{SD}=€ 13,799)$ per patient/year when productivity losses associated with sick leave and early retirement are considered, as well as patient out-ofpocket expenditures. ${ }^{711}$ Mean annual costs were reported to be in the range of $€ 8322-€ 41,327( \pm € 31,263) /$ patient in patients with moderate MS severity (EDSS 4-6.5) and from $€ 6485-€ 39,592( \pm € 37,785) /$ patient in patients with severe disease (EDSS 7-9.5).7,9

As there is no current curative therapy for MS, disease management is focused on reducing risk of relapses and disability progression. ${ }^{12}$ Disease-modifying therapies (DMTs) may reduce the development of central nervous system (CNS) lesions as well as frequency of exacerbations, and hence delay physical and cognitive deterioration. ${ }^{1}$ The first DMTs were approved in the 1990s (injectable therapies with IFN $\beta$ ). ${ }^{12}$ In recent years, a new generation of therapies have become available with a higher efficacy profile and a favourable impact on the patient's Quality of Life (QoL).

Alemtuzumab is a humanized monoclonal antibody licenced for treatment of adult patients with RRMS with active disease confirmed by clinical or imaging examination. ${ }^{13}$ A sustained treatment effect was demonstrated during clinical investigation and in the pivotal phase 3 randomized, dose-blinded, active-comparator trials in more than 1000 RRMS patients (CARE-MS I and CARE-MS II). ${ }^{14,15}$ Recent findings from the CARE-MS extension programme (median follow-up of 6years) indicated durable efficacy (magnetic resonance imaging (MRI) outcomes, reduction in brain volume loss and improvement in preexisting disability) in the absence of continuous treatment beyond the initial two treatment courses. ${ }^{16-18}$ During 6years of follow-up, the majority of patients did not receive additional alemtuzumab courses and their clinical and MRI disease activity remained low. ${ }^{19}$

At the time of writing, alemtuzumab, with its long-term biological effect, is the only treatment reimbursed in Italy for active RRMS disease with a sustained treatment effect and convenient administration: only two initial treatment courses, with up to two additional treatment courses, if needed (second treatment course to be administered 12 months after the first treatment course; third or fourth course, if needed, to be administered no less than 12 months after the prior treatment course)..$^{13}$ Alemtuzumab is currently licenced for adult patients with RRMS with active disease defined by clinical or imaging features. ${ }^{20}$ Alemtuzumab is recommended in the management of RRMS patients by health-technology assessment (HTA) and decision-making bodies across severaljurisdictions. ${ }^{21-23}$ In Italy, alemtuzumab, like fingolimod and natalizumab, is reimbursed in ${ }^{24-26}$

- RRMS patients with active disease despite prior treatment course with at least one disease-modifying agent therapy

- RRMS patients with rapid evolving severe disease ${ }^{26}$

Of note, the EMA (European Medicines Agency) has recently recommended the immediate suspension and recall of the MS therapy daclizumab beta following 12 reports of serious inflammatory brain disorders worldwide, including encephalitis and meningoencephalitis. For this reason, daclizumab was not included in this analysis. ${ }^{27}$

The aim of this research was to assess the health and economic outcomes associated with alemtuzumab therapy in comparison with the active comparator of the clinical programme CARE-MS (IFN $\beta$-1a $44 \mu \mathrm{g}$ ) and the other DMTs currently reimbursed in Italy in the same RRMS patient population as alemtuzumab (natalizumab and fingolimod).

\section{Methods}

A Markov model was developed to assess long-term clinical outcomes and costs of RRMS management associated with alemtuzumab in comparison with IFN $\beta-1 \mathrm{a} 44 \mu \mathrm{g}$, natalizumab $300 \mathrm{mg}$ and fingolimod $0.5 \mathrm{mg}$. Health effects were expressed as quality-adjusted life years (QALYs), while costs were expressed in Euro $(€, 2017)$. Costeffectiveness analysis and use of QALYs were selected as the most appropriate to assess outcomes of a chronic condition associated with reduced life expectancy and elevated morbidity, such as RRMS. The model structure was based on the previously published School of Health and Related Research (ScHARR) model, developed to evaluate 
cost-effectiveness of four DMTs in patients with RRMS and SPMS. ${ }^{28}$ Model health-states were based on the Kurtzke ${ }^{29}$ EDSS, 0-9 scale (Part I: Supplementary Appendix). EDSS 10 (MS-related death) was not accounted for as an individual health-state and mortality was captured separately, to allow for an increasing risk of mortality by age. Given the chronic nature of the disease, the model followed yearly cycles and evaluated effects and costs over the lifetime horizon (i.e. 50 years). The cohort of RRMS patients was distributed across the health-states (EDSS 0-9) at model initiation, allowing patients to progress/improve (transition to a healthstate with a higher/lower EDSS score, or progress to SPMS), remain in the same health-state or die. Model schematic is shown in Figure S1 (Supplementary Appendix).

Italian evidence was used wherever possible in order to appropriately reflect treatment patterns in the Italian context. Inputs related to disease, treatment and adverse event (AE) management were aligned with local data and validated with clinical expert judgement. Model assumptions were consistent with those of the costeffectiveness model published within the UK HTA authority that resulted in a positive recommendation by National Institute for Health and Care Excellence (NICE). ${ }^{23}$ Costs and effects were discounted at an annual 3.5\% rate, in line with the UK NICE ${ }^{23,30}$ recommendations and hence, alemtuzumab cost-effectiveness model previously submitted to the UK HTA authority. This approach was deemed appropriate as it already had precedents in published Italian literature. ${ }^{31,32}$ The analysis was performed from the national payer perspective (SSN, Servizio Sanitario Nazionale) in Italy.

\section{Model population}

The modelled patient population female to male ratio (1.9), and mean age of the cohort at the start of the model (34 years) were similar to the pooled alemtuzumab clinical trials cohorts (CARE-MS I and CARE-MS II). The CARE-MS I and II cohorts were deemed comparable to those in pivotal studies of comparator treatments, in terms of share of RRMS patients in the cohort ( $\geqslant 80 \%$ ), female to male ratio, mean age and mean EDSS score at baseline (Table S2, Supplementary Appendix).

\section{Health effects}

Data on natural disease history provided information on how MS patients progress in disease severity in the absence of treatment. These data were derived from the two large MS-population databases: the British Columbia Multiple Sclerosis (BCMS) ${ }^{33}$ database and the London Ontario dataset (observational registry with longitudinal data collection on MS patients during 1972-2000 period) for the EDSS states where transitions were not available (EDSS 7-9). The BCMS database covers $>80 \%$ of the MS population in British Columbia and includes disability worsening data, recorded at the individual patient-level for over 28 years of prospective follow-up. Use of BCMS data was deemed appropriate as it was consistent with NICE considerations on modelling of MS natural history. ${ }^{34}$ Natural history of RRMS was captured as a probability of being in any of the defined health-states of the Markov model [EDSS scores] at a given point in time (Table S3, Supplementary Appendix, provides matrices for transitions based on MS natural history).

Patients entered the model on active treatment with a DMT and moved on to best supportive care (BSC) after DMT withdrawal. The cohort of RRMS patients was distributed across EDSS health-states, based on the distribution of the pooled alemtuzumab cohorts in the CARE-MS I and CARE-MS II trials at baseline (Table 1).

Disease progression was simulated using three key parameters: disability progression, incidence of relapse and mortality:

- Disability progression: Table S3, Supplementary Appendix, shows transition matrices based on the natural history of RRMS. Progression to SPMS was not influenced by pharmacological treatment based on information from the London Ontario database (data from BCMS were not available; Table S4, Supplementary Appendix). Treatment effect on disability progression was derived from the network meta-analysis (NMA). ${ }^{37}$ An overview of hazard ratios (HRs) for respective treatments versus placebo is provided in Table 2.

- Incidence of relapse: The rate of relapses modelled in the economic analysis was EDSS state-dependant. Due to the lack of relapse data from the London Ontario or alternative registries, a literature search was conducted. Relapse rates were modelled based on the information from Held et al., ${ }^{38}$ as this study was based on a larger sample size and offered more recent evidence in comparison to the other reviewed sources. The relationship between relapse rate and time since diagnosis was informed from the regression analysis from Patzold et al. ${ }^{39}$ Relative risk of relapse versus placebo for each treatment was derived from the NMA, as reported in Table 2.

- Mortality: Mortality was not impacted by treatment. It was associated with population age and sex based on data from the Italian National Institute of Statistics (ISTAT). It was adjusted by mortality risk associated with increased EDSS scores ${ }^{40}$ (Table S5, Supplementary Appendix).

Transition probabilities were contingent on patients' EDSS score and constant over time. At any time, patients experienced a fixed rate of progression or relapse depending only on their current health-state (i.e. EDSS score). 
Table I. Overview of the EDSS health-states (distribution of patients at baseline, mean utility per health-state and mean cost of MS per health-state). ${ }^{\mathrm{a}}$

\begin{tabular}{|c|c|c|c|c|c|c|c|c|c|c|}
\hline $\begin{array}{l}\text { Health-state (EDSS score)/ } \\
\text { distribution in each }\end{array}$ & 0 & 1 & 2 & 3 & 4 & 5 & 6 & 7 & 8 & 9 \\
\hline CARE MS II5 & $4.35 \%$ & $32.70 \%$ & $40.00 \%$ & $22.61 \%$ & $0.35 \%$ & $0.00 \%$ & $0.00 \%$ & $0.00 \%$ & $0.00 \%$ & $0.00 \%$ \\
\hline CARE MS II'4 & $3.15 \%$ & $20.87 \%$ & $27.78 \%$ & $25.08 \%$ & $15.62 \%$ & $7.06 \%$ & $0.45 \%$ & $0.00 \%$ & $0.00 \%$ & $0.00 \%$ \\
\hline Pooled ${ }^{35}$ & $3.71 \%$ & $26.35 \%$ & $33.44 \%$ & $23.93 \%$ & $8.54 \%$ & $3.79 \%$ & $0.24 \%$ & $0.00 \%$ & $0.00 \%$ & $0.00 \%$ \\
\hline Mean health-state utility ${ }^{36}$ & 0.870 & 0.800 & 0.710 & 0.570 & 0.610 & 0.520 & 0.460 & 0.300 & -0.050 & -0.200 \\
\hline $\begin{array}{l}\text { Rate of relapse due to natural } \\
\text { history of the disease }{ }^{36}\end{array}$ & 0.905 & 0.905 & 0.895 & 0.899 & 0.900 & 0.881 & 0.859 & 0.856 & 0.856 & 0.856 \\
\hline Mean cost $t^{b}$ per state ${ }^{7}$ & $€ 3108$ & $€ 3108$ & $€ 3108$ & $€ 3108$ & $€ I I, 279$ & $€ I I, 279$ & $€ \mid I, 279$ & $€ 9469$ & $€ 9469$ & $€ 9469$ \\
\hline
\end{tabular}

EDSS: Expanded Disability Status Scale; MS: multiple sclerosis.

aFor items where standard error was not available in the source, a $\pm 20 \%$ parameter variation was assumed.

bInflated to 2017.

Table 2. Efficacy parameters based on the NMA.38.

\begin{tabular}{llll}
\hline Treatment & $\begin{array}{l}\text { Disability progression } \\
\text { HR vs placebo }(95 \% \mathrm{Cl})\end{array}$ & $\begin{array}{l}\text { RR of relapse vs placebo } \\
(95 \% \mathrm{Cl})\end{array}$ & $\begin{array}{l}\text { Annual rate of treatment } \\
\text { withdrawal }\end{array}$ \\
\hline Alemtuzumab I2 mg & $0.42[0.25,0.68]$ & $0.28[0.22,0.35]$ & 0.02 \\
IFN $\beta$-Ia 44 Hg & $0.73[0.52,0.99]$ & $0.64[0.54,0.73]$ & 0.09 \\
Natalizumab $300 \mathrm{mg}$ & $0.46[0.31,0.77]$ & $0.31[0.25,0.40]$ & 0.05 \\
Fingolimod 0.5 mg & $0.67[0.48,0.92]$ & $0.46[0.39,0.55]$ & 0.08 \\
\hline
\end{tabular}

NMA: network meta-analysis; RR: relative risk; $\mathrm{Cl}$ : confidence interval; HR: hazard ratio; CDW: confirmed disability worsening.

aThe Institute for Clinical and Economic Review NMA primarily utilized confirmed disability worsening at 6 months (CDW 6; referred to as sustained accumulation of disability (SAD 6) in the report) and CDW at 3 months (CDW 3; SAD 3 in the report) when CDW 6 was not available. Thus, the two outcomes were utilized to maximize data availability for the NMA.

Treatment effect on natural disease history was captured as a reduction in disability worsening and reduction in the frequency of relapse. With no head-to-head data for comparator therapies available, evidence from a NMA conducted by the Institute for Clinical and Economic Review on DMTs for RRMS ${ }^{37}$ was utilized to inform comparative clinical effectiveness for the model (Part IV, Supplementary Appendix, provides details on the NMA).

The annual rate of treatment withdrawal was derived from the NMA(Table 2). Due to the sustained effect of alemtuzumab long after administration, the impact of withdrawing alemtuzumab is assumed to be nil. ${ }^{41}$ This assumption was in line with the cost-effectiveness analysis from the NICE technology appraisal of alemtuzumab [TA312].23

\section{AEs}

This cost-effectiveness model included AE with at least $4 \%$ difference between intervention and control treatment (comparator) and those included in the prior HTAs of DMTs in RRMS population. Table 3 provides overview of the frequency and assumed duration of the AE included in the model. Furthermore, the model includes the frequency of treatment effect on relapse severity as reduction of $\mathrm{AE}$ related to diseases progression. This was accounted for as relative treatment effect on proportion of patients with a relapse which leads to hospitalization (Table 4).

\section{Health utilities}

The international literature was searched and reviewed for information on utilities in the MS population specifically in Italy. Due to the absence of Italian data, evidence on health utilities was derived from a UK population-based survey of MS patients and their caregivers. ${ }^{36}$ The European Quality of Life - 5 Dimensions (EQ-5D) utility scoring system was applied, with respondent domain scores converted to a single utility weight using the UK value set. ${ }^{36}$ Health utilities were applied based on disease severity (EDSS score) (Table 1). Each AE and relapse episode was associated with a utility decrement (i.e. disutility), applied for the duration of the AE or relapse. Utility decrement at relapse was assumed to last for 3 months and thereafter yearly values were calculated and applied in the model. Disutilities of 0.236 and 0.071 were associated with episodes of relapse leading to hospitalization and relapse not leading to hospitalization, respectively. ${ }^{36}$

\section{Resource use and costs}

The model accounted for the costs of therapies (drug acquisition and administration costs and treatment follow-up), cost of AE management and cost of relapse with and without hospitalization (Tables 5 and 6). The 
Table 3. AEs associated with DMT in the model: frequency (in year I and subsequent years post treatment initiation), associated disutility and cost per event. ${ }^{\mathrm{a}}$

\begin{tabular}{|c|c|c|c|c|c|c|}
\hline \multirow[t]{2}{*}{ Treatment } & \multicolumn{3}{|l|}{ AE frequency } & \multirow{2}{*}{$\begin{array}{l}\text { Disutility } \\
\text { (Source) }\end{array}$} & \multicolumn{2}{|l|}{ Cost of $\mathrm{AE}$} \\
\hline & Event & YI & $\mathrm{YI}+$ & & Event cost $(€)$ & $\begin{array}{l}\text { Health care resources consumption for AEs } \\
\text { management }\end{array}$ \\
\hline \multirow[t]{9}{*}{$\begin{array}{l}\text { Alemtuzumab } \\
12 \mathrm{mg}^{42}\end{array}$} & $\begin{array}{l}\text { Infusion-associated } \\
\text { reaction }\end{array}$ & $86.4 \%$ & $53.9 \%$ & $-0.0002^{43}$ & - & Included in the cost of administration \\
\hline & Cytopenia & $16.8 \%$ & $1 \mathrm{I} .0 \%$ & $-0.0002^{b}$ & 5.75 & Complete blood exam and biochemistry test \\
\hline & Urinary tract infection & $11.3 \%$ & $10.1 \%$ & $-0.0039^{44}$ & 24.38 & $\begin{array}{l}\text { I specialist visit; therapy with } 160+800 \mathrm{mg} \\
\text { Trimethoprim sulphometoxasol }\end{array}$ \\
\hline & Vomiting & $7.0 \%$ & $4.9 \%$ & $-0.0020^{45}$ & - & Included in the cost of administration \\
\hline & Bronchitis & $3.8 \%$ & $3.8 \%$ & $-0.0004^{46}$ & 22.02 & $\begin{array}{l}\text { I specialist visit; antibiotic (Amoxicillin I g/ } \\
\text { diem } \times 5 \text { days) }\end{array}$ \\
\hline & $\begin{array}{l}\text { Autoimmune thyroid- } \\
\text { related } \mathrm{AE}\end{array}$ & $5.7 \%$ & $9.1 \%$ & $-0.1081^{47}$ & 453 & $\begin{array}{l}3 \text { specialist visits; } 4 \text { diagnostic exams; I thyroid } \\
\text { biopsy; I ultrasound exam; therapy with } \\
\text { Levothyroxine } \times 12 \text { months (hypothyroidism) } \\
\text { or Tapazol (hyperthyroidism) }\end{array}$ \\
\hline & Herpes zoster & $2.0 \%$ & $2.2 \%$ & $-0.0046^{48}$ & 25.04 & $\begin{array}{l}\text { Antiviral therapy per os } 800 \mathrm{mg} / 7 \text { per } \\
\text { diem } \times 5 \text { days }\end{array}$ \\
\hline & Nephropathy & $0.1 \%$ & $0.1 \%$ & -0.8700 & 123.96 & $6 / 8$ nephrologist visit \\
\hline & $\begin{array}{l}\text { Idiopathic } \\
\text { thrombocytopenic } \\
\text { purpura (ITP) }\end{array}$ & $0.2 \%$ & $0.4 \%$ & -0.0065 & 2889.67 & $\begin{array}{l}\text { ITP (observation only) duration I month } \\
\text { ITP (steroids only) duration } 2 \text { months } \\
\text { ITP (steroids and immunoglobulin) duration } \\
\text { I month } \\
\text { ITP (steroids and rituximab } \pm \text { immunoglobulin), } \\
\text { duration } 3 \text { months } \\
\text { ITP (steroids and splenectomy) duration I year }\end{array}$ \\
\hline \multirow[t]{6}{*}{ Natalizumab 44,49} & Headache & $19.0 \%$ & $19.0 \%$ & $-0.0002^{50}$ & 20.66 & I GP visit \\
\hline & Fatigue & $13.5 \%$ & $13.5 \%$ & $-0.0014^{51}$ & 20.66 & I GP visit \\
\hline & Arthralgia & $9.5 \%$ & $9.5 \%$ & $-0.0034^{50}$ & 20.66 & I GP visit \\
\hline & Anaphylactic reaction & $0.7 \%$ & $0.1 \%$ & $-0.0194^{44}$ & 218 & DRG 447 allergic reactions (day-hospital) \\
\hline & Urinary tract infection & $2.0 \%$ & $2.0 \%$ & $-0.0039^{44}$ & 24.38 & $\begin{array}{l}\text { I specialist visit; therapy with } 160+800 \mathrm{mg} \\
\text { Trimethoprim sulphometoxasol }\end{array}$ \\
\hline & $\begin{array}{l}\text { Progressive Multifocal } \\
\text { Leukoencephalopathy }\end{array}$ & $0.02 \%$ & $0.1 \%$ & $-0.0078^{44}$ & 2184 & $\begin{array}{l}\text { DRG } 42 \text { I viral conditions ( }<17 \text { years) }(>\text { I day } \\
\text { recovery) }\end{array}$ \\
\hline \multirow[t]{4}{*}{ Fingolimod 52} & Macular edema & $0.2 \%$ & $0.2 \%$ & $-0.0100^{52}$ & 33.93 & $\begin{array}{l}2 \text { ophthalmologist visits; complete diagnostic } \\
\text { eye exam; partial diagnostic eye exam }\end{array}$ \\
\hline & $\begin{array}{l}\text { Atrioventricular block, } \\
\text { first degree }\end{array}$ & $0.1 \%$ & $0.1 \%$ & $-0.0008^{52}$ & 974 & $\begin{array}{l}\text { DRG I } 39 \text { arrhythmia and alterations of the } \\
\text { cardiac conduction (without complications) } \\
\text { ( }>\text { I day recovery) }\end{array}$ \\
\hline & $\begin{array}{l}\text { Atrioventricular block, } \\
\text { second degree }\end{array}$ & $0.1 \%$ & $0.1 \%$ & $-0.0008^{52}$ & 974 & $\begin{array}{l}\text { DRG I } 39 \text { arrhythmia and alterations of the } \\
\text { cardiac conduction (without complications) } \\
\text { ( }>\text { I day recovery) }\end{array}$ \\
\hline & Severe infection & $1.2 \%$ & $1.2 \%$ & $-0.0035^{48,52,53}$ & 11.29 & Assumption: Acyclovir $200 \mathrm{mg}, 5 \times$ diem \\
\hline IFN $\beta$-Ia & Injection-site reaction & $43.9 \%$ & $43.9 \%$ & $-0.0047^{43}$ & 20.66 & I GP visit \\
\hline \multirow[t]{2}{*}{$44 \mu g^{54-56}$} & Headache & $54.2 \%$ & $54.2 \%$ & -0.000251 & 20.66 & I GP visit \\
\hline & Fever & $65.0 \%$ & $65.0 \%$ & $-0.0343^{48}$ & 20.66 & I GP visit \\
\hline
\end{tabular}

AE: adverse event; DMT: disease-modifying therapy; GP: general practitioner; per diem: per day.

aFor items where standard error was not available in the source, a $\pm 20 \%$ parameter variation was assumed.

bAssumed the same disutility of that associated with injection site reaction.

international literature was searched and reviewed to retrieve average annual costs associated with EDSS severity. Several Italian studies were reviewed and Italian data on health care resource consumption from the international cost-of-illness study TRIBUNE in MS were used. $^{7}$ The study included $\mathrm{n}=251 \mathrm{MS}$ patients from Italy $\left(\mathrm{N}=1261\right.$ in Europe $\left.{ }^{11}\right)$ that largely matched patients' baseline characteristics from the CARE-MS trials (mean age $=37$ years, $>50 \%$ with no or limited disability, and only $1.6 \%$ with EDSS $\geqslant 7) .{ }^{7}$ Frequency of specialist visits, frequency of diagnostic follow-up exams associated with disease management, treatment follow-up and management of AEs in the RRMS population were derived based on the disease management guidelines from the Emilia Romagna region of Italy from 2016, ${ }^{59}$ and from expert opinion.

Because of a lack of published evidence on the cost of an MS relapse in Italy, the cost of one relapse episode not leading to hospitalization was derived based on primary data from the hospital centre Careggi in Florence using a micro-costing method and accounting for the cost of 
Table 4. Relative treatment effect on proportion of patients with a relapse which leads to hospitalization. ${ }^{\mathrm{a}}$

\begin{tabular}{|c|c|c|c|}
\hline Treatment & $\begin{array}{l}\text { Relative effect on } \\
\text { proportion leading to } \\
\text { hospitalization }\end{array}$ & Derivation and source & Assumption \\
\hline Alemtuzumab $12 \mathrm{mg}$ & 0.225 & $\begin{array}{l}\text { CARE-MS II (annualized relapse rate } \\
\text { leading to hospitalization: alemtuzumab } \\
\text { I } 2 \mathrm{mg} 0.05 \text {, interferon beta- I a } 44 \mu \mathrm{g} \\
0.1 \text { I) }=0.05 / 0.1 \text { I } \times 0.495^{57} \\
\text { (relative risk alemtuzumab I } 2 \mathrm{mg} \text { vs interferon } \\
\text { beta- I a } 44 \mu \mathrm{g} \times \text { relative risk interferon beta- I a } \\
44 \mu \mathrm{g} \text { vs placebo) }\end{array}$ & $\begin{array}{l}\text { Interferon beta- Ia } 44 \mu \mathrm{g} \\
\text { treatment effect assumed equal } \\
\text { to interferon beta-la } 30 \mu \mathrm{g}\end{array}$ \\
\hline IFN $\beta$ - Ia $44 \mu g$ & 0.495 & $\begin{array}{l}\text { TRANSFORMS: interferon beta- I a } 30 \mu \mathrm{g} \text { ( } 179 \\
\text { relapses, } 36 \text { hospitalized) } 20.1 \% \text {; FREEDOMS: } \\
\text { placebo ( } 359 \text { relapses, I } 46 \text { hospitalized) } 40.7 \% \text {; } \\
\text { risk vs placebo }-50.5 \%{ }^{58}\end{array}$ & $\begin{array}{l}\text { Assumed same as interferon } \\
\text { beta-Ia } 30 \mu g\end{array}$ \\
\hline Natalizumab $300 \mathrm{mg}$ & 0.600 & - & $\begin{array}{l}\text { Assumed same as Fingolimod } \\
0.5 \mathrm{mg}\end{array}$ \\
\hline Fingolimod $0.5 \mathrm{mg}$ & 0.600 & $\begin{array}{l}\text { TRANSFORMS: fingolimod } 0.5 \mathrm{mg} \text { ( } 89 \text { relapses, } \\
\text { I I hospitalized) I } 2.4 \% \text {; FREEDOMS: fingolimod } \\
0.5 \mathrm{mg} \text { (I72 relapses, } 63 \text { hospitalized) } 36.6 \% \text {; } \\
\text { FREEDOMS: placebo ( } 359 \text { relapses, } 146 \\
\text { hospitalized) } 40.7 \% \text {; risk vs placebo }-40 \%\end{array}$ & $\begin{array}{l}\text { Weighted average of fingolimod } \\
\text { risk of hospitalization } \\
\text { from FREEDOMS and } \\
\text { TRANSFORMS relative to } \\
\text { placebo arm of FREEDOMS } \\
\text { only }\end{array}$ \\
\hline
\end{tabular}

aFor items where standard error was not available in the source, a $\pm 20 \%$ parameter variation was assumed.

specialist visit, 1 MR scan and 15-day treatment with cortisone preparations (including costs of nursing and costs of disposable materials), which was €477/episode. The cost of a relapse episode leading to hospitalization was modelled based on the national tariff for DRG 13 'Multiple sclerosis and cerebral ataxia', in-patient admission (DRG 13-National tariff $€ 1417$ ). ${ }^{60}$

Ex-factory drug prices calculated with net of mandatory deductions (i.e. $-5 \% /-5 \%$ ) were retrieved from the Italian official journal (Gazzetta Ufficiale - G.U.). The cost of ambulatory visits was based on the National tariffs. ${ }^{60}$ Table 6 provides a complete overview of the resource use and cost data used in the model as well as underlying assumptions and sources.

\section{Analyses}

Health effects and costs were modelled for a lifetime horizon (assumed 50 years for a chronic condition) and all outcomes and effects were discounted using an annual $3.5 \%$ rate based on NICE recommendations. ${ }^{61}$ Therapies were modelled in line with the prescribing criteria of RRMS therapies in Italy (Nota AIFA 65: IFN $\beta$-1a prescribed for RRMS EDSS 0-5.5 and DMT discontinued in case of progression to SPMS). ${ }^{62}$ The overall costs and utilities of each treatment were calculated by multiplying the number of patients in each state at the beginning of each cycle by the corresponding utility and cost values, and then summing across health-states and model cycles. Mean per patient cost was derived by dividing the total mean cost by number of alive patients at the end of each cycle. Estimated mean costs are contingent on patient transition across health-states (based on EDSS score) and time spent at each health-state.

Parameter uncertainty was assessed by means of deterministic one-way sensitivity analysis (OWSA) and probabilistic sensitivity analyses (PSAs).

Key model parameters were varied independently over a plausible range determined by the standard error of each variable. For parameters where a measure of uncertainty was not available, the range was estimated using an arbitrary $\pm 20 \%$ variation around the point estimate. For PSA, parameters were assigned a distribution (Table S7, Supplementary Appendix) based on the underlying data and in line with good modelling practice. ${ }^{63}$ PSA was performed by varying key model parameters simultaneously and randomly within their probability distribution. It was conducted using 1000 Monte Carlo iterations. The Incremental Cost-Effectiveness Ratio (ICER) was contrasted against the unofficial acceptability range (€25,000-€40,000) as proposed by Fattore G per Gruppo di lavoro Associazione Italiana di Economia Sanitaria (AIES). ${ }^{64}$

In addition, cost-effectiveness of alemtuzumab in RRMS population was assessed in ad hoc scenario analyses:

- Discount rate variation $0 \% / 5 \%$ for costs and outcomes

- Time horizon alteration: 15 years

- Societal perspective including productivity losses due to short-term absence and reduced working time/ income were derived from the TRIBUNE study ${ }^{7}$ 
Table 5. Drug acquisition and administration costs (€, 20I7). ${ }^{\mathrm{a}}$

\begin{tabular}{|c|c|c|c|c|c|c|}
\hline & Posology & $\begin{array}{l}\text { Acquisition } \\
\text { costs year I }\end{array}$ & $\begin{array}{l}\text { Acquisition } \\
\text { costs year } 2+\end{array}$ & $\begin{array}{l}\text { Administration } \\
\text { cost year I }\end{array}$ & $\begin{array}{l}\text { Administration } \\
\text { cost subsequent } \\
\text { years }\end{array}$ & Source \\
\hline Alemtuzumab & $\begin{array}{l}\text { I st cycle: } 12 \mathrm{mg} / \text { day for } 5 \\
\text { consecutive days (total of } \\
60 \mathrm{mg} \text { ) } \\
2 \text { nd cycle: } 12 \mathrm{mg} / \text { day } \\
\text { for } 3 \text { consecutive days } \\
\text { administered I } 2 \text { months } \\
\text { after the first treatment } \\
\text { course } \\
\text { Up to two additional } \\
\text { treatment courses, } \\
\text { as-needed, } \\
\text { Third or fourth course: } \\
12 \text { mg/day on } 3 \text { consecutive } \\
\text { days ( } 36 \text { mg total dose) } \\
\text { administered at least } \\
12 \text { months after the prior } \\
\text { treatment course }\end{array}$ & $€ 39,765$ & $€ 23,859$ & $\begin{array}{l}€ I 855^{\circ}(5 \\
\text { infusions/year) }\end{array}$ & $\begin{array}{l}€ I I I 3^{c}(3 \\
\text { infusions per } \\
\text { year) }\end{array}$ & $\begin{array}{l}{ }^{60} \text { Agenzia Italiana } \\
\text { del Farmaco. Det. } \\
23 \text { marzo } 2015 \\
\text { (G.U. n82 del } \\
\text { 9-4-20I5). }\end{array}$ \\
\hline Natalizumab & $\begin{array}{l}300 \mathrm{mg} \text { IV infusion every } \\
4 \text { weeks }\end{array}$ & $€ 21,177$ & $€ 21,177$ & $\begin{array}{l}€ 4823^{b} \text { (I } 3 \\
\text { infusions per } \\
\text { year) }\end{array}$ & $\begin{array}{l}€ 4823^{b} \text { (I } 3 \\
\text { infusions per } \\
\text { year) }\end{array}$ & $\begin{array}{l}{ }^{60} \text { Agenzia Italiana } \\
\text { del Farmaco. Det. } \\
7 \text { dicembre } 2006 \\
\text { (G.U. n292 del } \\
\text { I6-I2-2006) }\end{array}$ \\
\hline Fingolimod & $0.5 \mathrm{~g}$ cps. per os/day & $€ 21,177$ & $€ 21,177$ & $€ 78^{d}$ & - & $\begin{array}{l}\text { Agenzia Italiana } \\
\text { del Farmaco. Det. } \\
8 \text { novembre } 20 \text { I I } \\
\text { (G.U. n272 del } \\
\text { 22-II-20II) }\end{array}$ \\
\hline IFN $\beta$ - Ia $44 \mu \mathrm{g}$ & $44 \mu g$ s.c. inj 3 per week & $€|2,09|$ & $€|2,09|$ & $€ 52$ & - & $\begin{array}{l}\text { Agenzia Italiana del } \\
\text { Farmaco. Decreto } \\
29 \text { Dicembre } \\
\text { 1999-Gazzetta n. } \\
\text { I3 del I8 gennaio } \\
2000\end{array}$ \\
\hline
\end{tabular}

IV: intravenous; inj: injection; s.c.: subcutaneous.

aFor items where standard error was not available in the source, a $\pm 20 \%$ parameter variation was assumed.

bTreatment rates with third and fourth courses retrieved from the extension studies CARE MS I and CARE MS II.

cNational Tariff DRG 4/0.

dPatient education and monitoring - specialist $(€ 60)$ and nurse (€26) hourly cost (Source: Hospital Careggi, Florence - Management Control $180 \mathrm{~min}$ of specialist time for cardiac monitoring and $120 \mathrm{~min}$ of nurse time for patient education).

- Based on expert opinion, some regional centres in Italy may implement more frequent follow-up schedule in RRMS management than that reported by the guidelines for specific patient populations. Thus, frequency of treatment follow-up visits in this scenario analysis was based on clinical practice of an Italian large regional MS centre (University Hospital Orbassano, Piedmont) (Table S6, Supplementary Appendix).

Internal validity was confirmed by comparing the distribution of patients across EDSS states with that from the pooled CARE-MS I and CARE-MS II trial populations at year 2 .

\section{Results}

Treatment with alemtuzumab was more effective than other assessed therapies, with accrued incremental benefits over a lifetime in the range of 1.03-1.62 QALYs in comparison with natalizumab and IFN $\beta-1 \mathrm{a}$, respectively. Alemtuzumab cohort yielded the lowest cumulative number of relapses over a lifetime (a cumulative for both relapses that do not require hospitalization as well as those which require hospitalization) (Figure S5 Supplementary Appendix). Cumulative number of relapses over a lifetime in alemtuzumab cohort was 27.86 , whereas it was 28.66 in fingolimod cohort, 29.25 in natalizumab cohort and 30.64 in IFN $\beta$-1a cohort. 
Table 6. Resource use and cost associated with treatment follow-up.

\begin{tabular}{|c|c|c|c|c|c|c|c|c|c|}
\hline \multirow[t]{2}{*}{ Parameter } & \multirow{2}{*}{$\begin{array}{l}\text { Unit } \\
\operatorname{cost}^{60}\end{array}$} & \multicolumn{2}{|c|}{ Alemtuzumab } & \multicolumn{2}{|c|}{ Natalizumab"l } & \multicolumn{2}{|c|}{ Fingolimod"I } & \multicolumn{2}{|l|}{ IFN $\beta-\mathrm{Ia}$} \\
\hline & & $\begin{array}{l}\text { Frequency } \\
\text { Y I }\end{array}$ & $\begin{array}{l}\text { Frequency } \\
\text { Y } 2+\end{array}$ & $\begin{array}{l}\text { Frequency } \\
\text { Y I }\end{array}$ & $\begin{array}{l}\text { Frequency } \\
\text { Y } 2+\end{array}$ & $\begin{array}{l}\text { Frequency } \\
\text { Y I }\end{array}$ & $\begin{array}{l}\text { Frequency } \\
\text { Y } 2+\end{array}$ & $\begin{array}{l}\text { Frequency } \\
\text { Y I }\end{array}$ & $\begin{array}{l}\text { Frequency } \\
\text { Y } 2+\end{array}$ \\
\hline $\begin{array}{l}\text { Biochemistry } \\
\text { test }^{\mathrm{a}}+\text { full blood } \\
\text { count }^{\mathrm{b}}\end{array}$ & $€ 2.6$ & 13 & 13 & 14 & 13 & 6 & 5 & 4 & 2 \\
\hline MRI scanc & $€ 247.5$ & - & - & 2 & 2 & 3 & 2 & - & - \\
\hline $\begin{array}{l}\text { Ophthalmology } \\
\text { visit (treatment } \\
\text { initiation) })^{d}\end{array}$ & $€ 20.7$ & - & - & - & - & I & - & - & - \\
\hline Neurology visit & $€ 20.7$ & 7 & 5 & 13 & 12 & 4 & 3 & 4 & 4 \\
\hline Renal function test ${ }^{f}$ & $€ 2.3$ & 13 & 13 & II & 13 & 6 & 5 & - & \\
\hline $\begin{array}{l}\text { Hepatic functional } \\
\text { test }^{g}\end{array}$ & $€ 2.0$ & 13 & 13 & - & - & - & - & 4 & 2 \\
\hline HPV test $\mathrm{t}^{\mathrm{h}}$ & $€ 31.8$ & I & 1 & I & - & I & - & & - \\
\hline Tuberculin skin test $\mathrm{t}^{\mathrm{i}}$ & $€ 32.2$ & I & I & I & - & I & - & - & - \\
\hline MS nurse visitsi & $€ 3.25$ & I & I & 1 & - & I & - & - & - \\
\hline $\begin{array}{l}\text { Mean annual total } \\
\text { cost }\end{array}$ & 1 & $€ 854$ & $€ 812$ & $€ 999$ & $€ 921$ & $€ 991$ & $€ 625$ & $€ 248$ & $€ 166$ \\
\hline
\end{tabular}

HPV: human papilloma virus; MRI: magnet resonance imaging; MS: multiple sclerosis: PML: Progressive Multifocal Leukoencephalopathy. a91.49.2 Prelievo di sangue venoso (Venoos blood sampling).

b90.62.2 Emocromo (complete blood count) (Hb, GR, GB, HCT, PLT, IND. DERIV., F. L.).

88.91.2 Risonanza magnetica nucleare (RM) del cervello e del tronco encefalico, senza e con contrasto (Magnetic resonance imaging - brain and brainstem - with or without contrast).

d95.02 Esame complessivo dell'occhio prima visita oculistica. Incluso: esame del visus, refrazione con eventuale prescrizione di lenti, tonometria, biomicroscopia, fundus oculi con o senza midriasi farmacologica (Complete eye exam including physician visit; Including: exam of eye visus, refraction with or without prescription of lenses, tonometry, biomicroscopy, fundus oculi with or without pharmacological mydriasis).

e89.13 Visita neurologica (Physician visit - neurologist).

990.44.3 e 90.44.2 Urine esame chimico fisico e microscopico e conta di addis (Urine examination including Addis count).

890.09.2 Aspartato aminotransferasi (AST) (Aspartate aminotransferase) (GOT) [S] + 90.04.5 Alanina Aminotransferasi (ALT) (Alanin aminotransferase) (GPR) [S/U].

h91.38.5 ES. citologico cervico vaginale (Cytological exam of vaginal cervix) [PAP test] + 89.26 visita ginecologica (Physician visit - gynecologist). 90.42.I Tireotropina (TSH) (Thyrotropin), 90.42.3 tiroxina libera (FT4) (Free Thyroxin), 90.5I.4 anticorpi anti microsomi (AbTMS) o anti tireoperossidasi (AbTPO) (Antithyroid microsomal antibody or Thyroid peroxidase antibody test), 90.54 .4 anticorpi anti tireoglobulina (AbTg) (Thyroid Antithyroglobulin Antibody).

iUsed as a proxy, the cost of nurse assistance in private practice in hospital outpatient setting (intramoenia) L'aziendalizzazione della sanità in Italia: rapporto OASI 2003. Milano .EGEA .2003.k

Alemtuzumab showed cost-savings in comparison with all other assessed DMTs (Table 7).

In terms of the cost-effectiveness comparison, alemtuzumab was dominant (yielding better outcomes at reduced cost) in comparison with all assessed DMTs in the base-case analysis.

A multiple cost-effectiveness acceptability curve (CEAC) was constructed, which showed that the ICER of alemtuzumab carries the highest likelihood of being below a commonly accepted willingness-to-pay (WTP) threshold in Italy ( $€ 40,000 / \mathrm{QALY}$ ) (below WTP in $52 \%$ of replications), compared to the other evaluated therapies (IFN $\beta-1 \mathrm{a}$ in $49 \%$, fingolimod in $6 \%$ and natalizumab in $3 \%$ of replications) (Figure 1).

Results of the deterministic sensitivity and scenario analyses are presented in a Tornado chart (Figure 2) displaying results of those analyses that had $\geqslant \pm 20 \%$ impact on the base-case ICER. Alteration of the annual discount rate and time horizon had the greatest impact on the base-case ICER. In addition, results were sensitive to the variation of disability progression HR of alemtuzumab and comparator treatments and change in comparator acquisition costs. However, alemtuzumab dominated IFN $\beta-1 \mathrm{a}$, fingolimod and natalizumab across all analyses. Results were somewhat sensitive to alteration of frequency of alemtuzumab follow-up visits with an impact of $6 \%$ and $15 \%$ on the base-case ICER in comparison versus natalizumab and versus fingolimod, respectively.

Following the societal viewpoint, alemtuzumab treatment was the dominant option in comparison to IFN $\beta-1 \mathrm{a}$, natalizumab and fingolimod with ICERs up to 3 times lower than in the base-case (Figure 2).

\section{Discussion}

DMT may reduce the development of neural lesions as well as frequency of exacerbations and hence delay physical and cognitive detriment in RRMS patients. ${ }^{1}$ DMTs require intravenous, oral, subcutaneous or intramuscular administration with variable frequencies, 
Table 7. Cost-effectiveness model results for lifetime horizon.

\begin{tabular}{|c|c|c|c|c|c|c|c|}
\hline & Alemtuzumab & $\begin{array}{l}\text { IFN } \beta-\text { Ia } \\
44 \mu g\end{array}$ & $\begin{array}{l}\Delta \text { to } \\
\text { alemtuzumab }\end{array}$ & Natalizumab & $\begin{array}{l}\Delta \text { to } \\
\text { alemtuzumab }\end{array}$ & Fingolimod & $\begin{array}{l}\Delta \text { to } \\
\text { alemtuzumab }\end{array}$ \\
\hline Total costs & $€ 377,413$ & $€ 38 I, 726$ & $(€ 43 \mid 2)$ & $€ 458,975$ & $(€ 81,562)$ & $€ 431,480$ & $(€ 54,067)$ \\
\hline Total disease cost & $€ 290,100$ & $€ 316,983$ & $(€ 26,882)$ & $€ 307,246$ & $(€|7| 45)$, & $€ 3|4,1| 5$ & $(€ 24,0 \mid 4)$ \\
\hline Relapse costs & $€ 10,350$ & $€ \mid 2,134$ & $(€ \mid 783)$ & $€ I I, 450$ & $(€|| 00)$ & $€ I I, 829$ & $(€ \mid 478)$ \\
\hline Therapy costs & $€ 75,027$ & $€ 63,576$ & $€ I I, 450$ & $€ \mid 19,247$ & $(€ 44,220)$ & $€|| 3,60 \mid$ & $(€ 38,574)$ \\
\hline Administration costs & $€ 3499$ & $€ 45$ & $€ 3454$ & $€ 27,158$ & $(€ 23,658)$ & $€ 68$ & $€ 3431$ \\
\hline Monitoring cost & $€ 8566$ & $€ 943$ & $€ 7623$ & $€ 5254$ & $€ 3312$ & $€ 3681$ & $€ 4885$ \\
\hline Cost of adverse event & $€ 218$ & $€ \mid 77$ & $€ 4 \mathrm{I}$ & $€ 68$ & $€ 150$ & $€ 13$ & $€ 205$ \\
\hline $\begin{array}{l}\text { Total Quality-Adjusted } \\
\text { Life Years (QALYs) }\end{array}$ & 7.11 & 5.49 & 1.62 & 6.08 & 1.03 & 5.75 & 1.36 \\
\hline $\begin{array}{l}\text { Incremental Cost- } \\
\text { Effectiveness Ratio } \\
\text { (ICER) }\end{array}$ & & & Dominant & & Dominant & & Dominant \\
\hline
\end{tabular}

All costs and effects were discounted using a $3.5 \%$ rate.

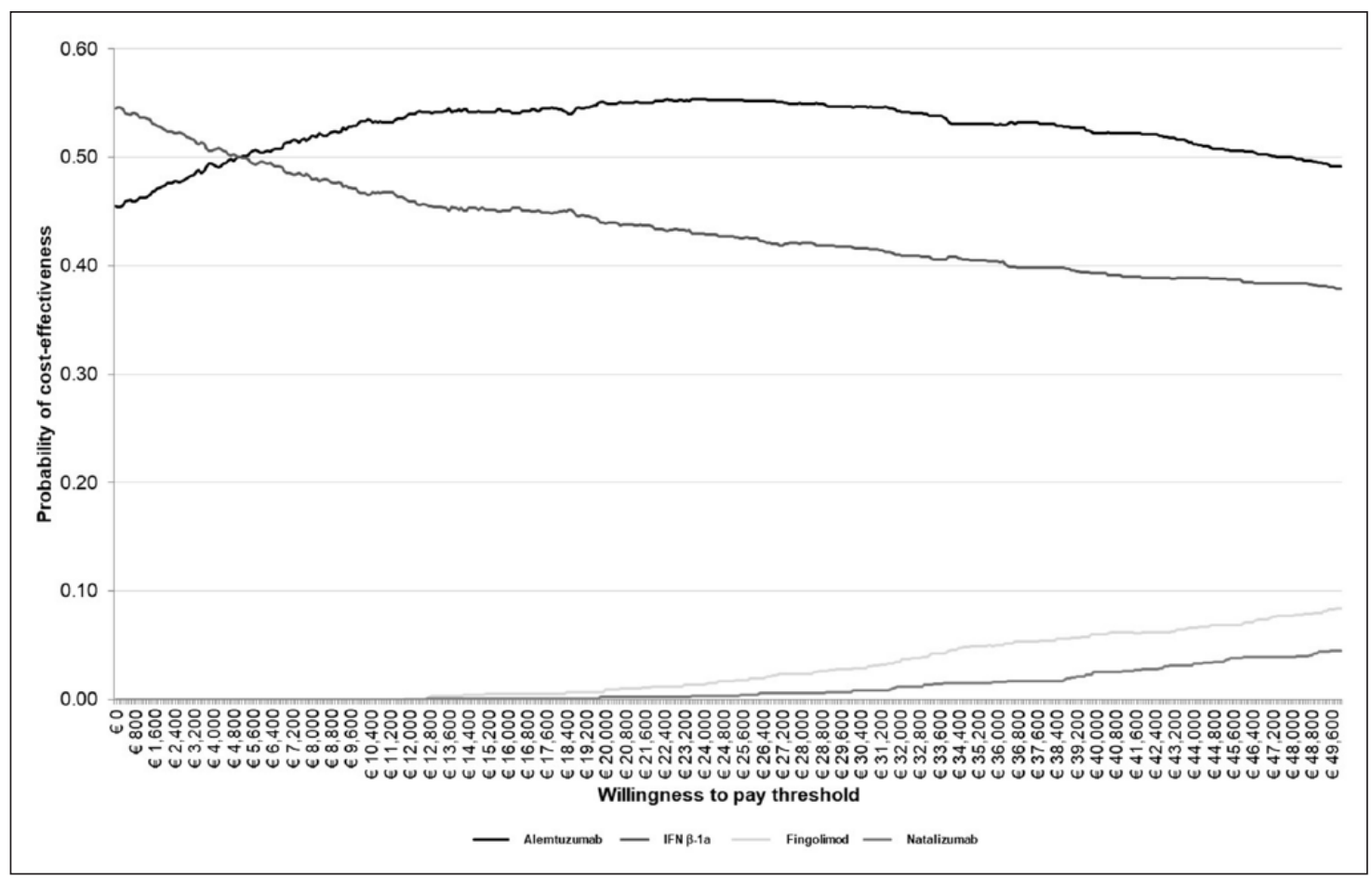

Figure I. Cost-effectiveness acceptability curve for alemtuzumab versus other disease-modifying therapies using a lifetime horizon.

depending on treatment. At present, alemtuzumab, due to its unique mode of action and prolonged therapeutic effect, offers sustained treatment benefit with a convenient administration schedule (two initial treatment courses with up to two additional treatment courses if needed (second treatment course: 12 months after the prior treatment course; third or fourth course: at least 12 months after the previous treatment course)). The efficacy of alemtuzumab versus active comparator (SC IFN $\beta$-1a) was established through a comprehensive clinical development programme. Evidence from the extension trials indicated durable treatment effect in the absence of additional treatment after the initial two courses. ${ }^{16-18}$ Given the high costs of lifetime MS management associated with DMT, it is important to demonstrate the impact of these therapies on long-term health effects including QoL, and hence prove their value in the context of substantial disease management costs. This work aimed to assess lifetime costs and effects associated with the use of alemtuzumab in the management of RRMS patients in Italy in comparison with the direct comparator from the CARE-MS trials (SC IFN $\beta$-1a) and in comparison, with the other DMTs currently reimbursed 


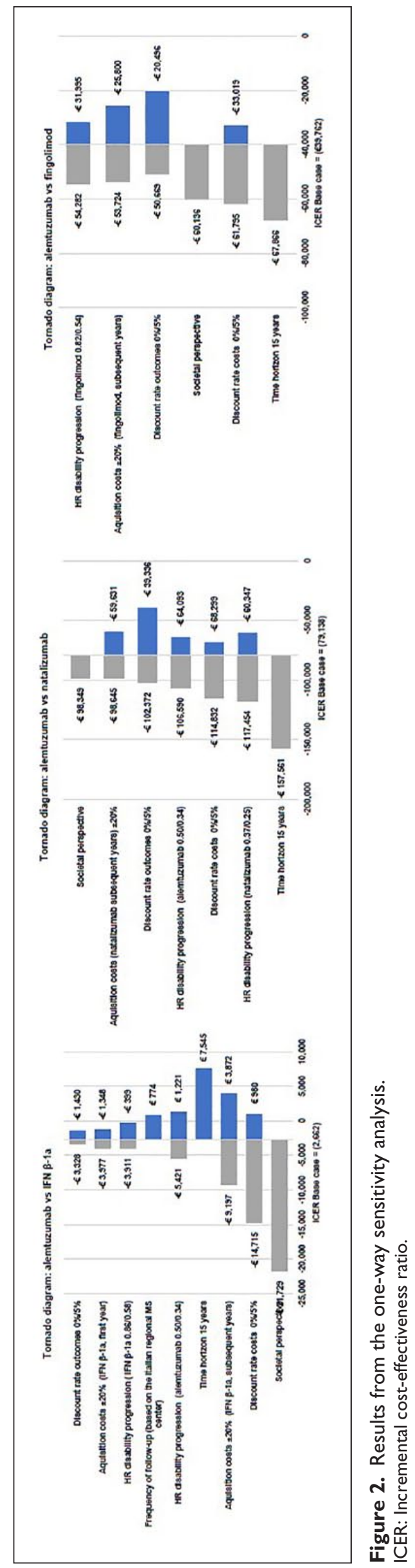


in Italy for the same patient population as alemtuzumab (i.e. natalizumab and fingolimod).

This analysis suggests that alemtuzumab is a costsaving option in the lifetime management of RRMS in Italy. Total treatment costs were largely driven by the underlying cost of disease management and drug therapy costs. Treatment with alemtuzumab was estimated to be less expensive than with IFN $\beta-1 \mathrm{a}$, fingolimod or natalizumab: this was driven primarily by lower disease management costs relative to the other treatments, with considerably less cost associated with relapse.

Our results show patients treated with alemtuzumab experience more QALYs (increment of 1.62 over IFN $\beta$ 1a), more years without the use of walking aids and fewer relapses than all comparators included in the base-case analyses. This confirms that alemtuzumab is more effective than those treatments in terms of preventing relapse and progression to higher EDSS states, in all base-case analyses. Although the cost of treatment follow-up for alemtuzumab was higher than with other analysed DMTs, alemtuzumab remained a cost-saving treatment option in comparison with IFN $\beta$ 1a, fingolimod and natalizumab even after increasing the annual frequency of follow-up visits to match what is in some cases at Local Health Unit level within the Italian SSN. Alemtuzumab remained a costsaving option in comparison with IFN $\beta$-1a, fingolimod and natalizumab across most $(>80 \%)$ sensitivity and scenario analyses.

Several works assessed the cost-effectiveness of DMTs from the Italian perspective; ${ }^{65-67}$ however, none assessed long-term effects and costs of alemtuzumab in RRMS patients. Dashputre et al..$^{68}$ and Montgomery et al. ${ }^{69}$ assessed alemtuzumab among other DMTs from the perspective of the third-party payer in the United States and the perspective of the National Health Service in the United Kingdom. Dashputre and colleagues assessed alemtuzumab therapy in comparison to IFN $1 \beta$ over the 2-year time horizon; their analysis showed alemtuzumab is a cost-effective treatment option in the United States with an accrued ICER of $\$ 25,276$ per relapse avoided at 2 years (a much shorter time horizon than the present study). Montgomery et al. evaluated use of alemtuzumab in comparison with fingolimod varying the discount price of fingolimod across various patient access scheme scenarios in the United Kingdom. Although fingolimod resulted in lower acquisition costs across all tested scenarios, those advantages were offset by lower disease management costs associated with fewer relapses in the modelled cohort treated with alemtuzumab. ${ }^{69}$

As any research, this cost-effective model has several limitations primarily stemming from the lack of evidence. In the lack of head-to-head comparison, the model was based on a published NMA. In addition, in the absence of local Italian tariffs for MS relapse management, a microcosting approach was used. Despite these limitations, sensitivity analyses demonstrated results were robust across most $(>80 \%)$ sensitivity and scenario analyses. Although the model designed allowed for a pairwise comparison of MS therapies, a multiple CEAC was constructed for a comparative analysis. At the time of manuscript submission, model programming features allowed for an OWSA around base-case ICER, while we acknowledge that an OWSA around net monetary benefit results may have provided additional information.

Alemtuzumab was shown to be a cost-saving treatment option in comparison to IFN $\beta$-1a $44 \mu \mathrm{g}$, natalizumab and fingolimod in the management of RRMS patients in Italy, notwithstanding its posology with a maximum of two additional treatment courses, if needed, after the initial treatment of two courses. The current study suggests that alemtuzumab is a preferable treatment option in the management of active or highly active RRMS in Italy.

\section{Declaration of conflicting interests}

Antonio Bertolotto is the Principal Investigator of the Project \# RF-2013-02357497 'Improving therapeutic appropriateness of Multiple Sclerosis treatments using biological approaches to personalize therapy and save pharmaceutical spending' supported by the Servizio Sanitario Italiano, Ricerca Finalizzata.

\section{Funding}

The study was supported by Sanofi SpA. through an unrestricted grant to Certara Italy Srl, Via G.B. Pirelli, 27 - Milano. No interferences occurred in carrying out the project and in writing the manuscript that is the sole responsibility of the authors.

\section{Supplemental material}

Supplemental material for this article is available online.

\section{ORCID iD}

Sanja Stanisic iD https://orcid.org/0000-0002-3219-5901

\section{References}

1. National Institute for Health and Care Excellence (NICE). Multiple sclerosis in adults: management (CG186). London: NICE, 2014.

2. Browne P, Chandraratna D, Angood C, et al. Atlas of multiple sclerosis 2013: a growing global problem with widespread inequity. Neurology 2014; 83(11): 1022-1024.

3. Kurtzke JF, Page WF, Murphy FM, et al. Epidemiology of multiple sclerosis in US veterans. 4. Age at onset. Neuroepidemiology 1992; 11(4-6): 226-235.

4. Associazione Italiana Sclerosi Multipla (AISM). Barometro della sclerosi multipla. Genoa: AISM, 2017.

5. Fattore G, Lang $M$ and Pugliatti $M$. The treatment experience, burden, and unmet needs (TRIBUNE) study - measuring the socioeconomic consequences of multiple sclerosis. Mult Scler 2012; 18(Suppl. 2): 5-6.

6. Ernstsson O, Gyllensten H, Alexanderson K, et al. Cost of illness of multiple sclerosis - a systematic review. PLoS ONE 2016; 11(7): e0159129. 
7. Karampampa K, Gustavsson A, Miltenburger C, et al. Treatment experience, burden and unmet needs (TRIBUNE) in MS study: results from Italy. Mult Scler 2012; 18(Suppl. 2): 29-34.

8. Kobelt G, Berg J, Lindgren P, et al. Costs and quality of life of multiple sclerosis in Italy. Eur J Health Econ 2006; 7(Suppl. 2): S45-S54.

9. P B, MP A, P B, et al. The direct cost of patients with multiple sclerosis: a survey from Italian MS centres. Neurol Sci 2011; 32(6): 1035-1041.

10. Paolucci S, Martinuzzi A, Scivoletto G, et al. Assessing and treating pain associated with stroke, multiple sclerosis, cerebral palsy, spinal cord injury and spasticity. Evidence and recommendations from the Italian consensus conference on pain in neurorehabilitation. Eur $J$ Phys Rehabil Med 2016; 52(6): 827-840.

11. Karampampa K, Gustavsson A, Miltenburger C, et al. Treatment experience, burden and unmet needs (TRIBUNE) in MS study: results from five European countries. Mult Scler 2012; 18(Suppl. 2): 7-15.

12. Montalban X, Gold R, Thompson AJ, et al. ECTRIMS/EAN guideline on the pharmacological treatment of people with multiple sclerosis. Mult Scler 2018; 24(2): 96-120.

13. Agenzia Italiana del Farmaco (AIFA). Riassunto delle caratteristiche del prodotto - Lemtrada ${ }^{\circledR}$ (aletuzumab). Rome: AIFA, 2018.

14. Cohen JA, Coles AJ, Arnold DL, et al. Alemtuzumab versus interferon beta $1 \mathrm{a}$ as first-line treatment for patients with relapsing-remitting multiple sclerosis: a randomised controlled phase 3 trial. Lancet 2012; 380(9856): 1819-1828.

15. Coles AJ, Twyman CL, Arnold DL, et al. Alemtuzumab for patients with relapsing multiple sclerosis after diseasemodifying therapy: a randomised controlled phase 3 trial. Lancet 2012; 380(9856): 1829-1839.

16. Arnold DL, Barnett M, Comi G, et al. Durable reduction in MRI disease activity with alemtuzumab in the absence of continuous treatment in patients with active relapsingremitting multiple sclerosis who were treatment-naive: 6-year follow-up of the CARE-MS I study (S10.002). In: Proceedings of the 32nd congress of the European committee for treatment and research in multiple sclerosis (ECTRIMS), 14-17 September 2016, London, UK.

17. Singer B, Coles AJ, Boyko AN, et al. Improvements in clinical outcomes with alemtuzumab in treatment-naive patients with active relapsing-remitting multiple sclerosis are durable over 6 years in the absence of continuous treatment (CARE-MS I) (S24.005). In: Proceedings of the 32 nd congress of the European committee for treatment and research in multiple sclerosis (ECTRIMS), 2016.

18. Traboulsee A, Barnett M, Comi G, et al. Alemtuzumab durably slows brain volume loss over 6 years in the absence of continuous treatment in patients with active RRMS who were treatment-naive (CARE-MS I) or had an inadequate response to prior therapy (CARE-MS II) (P2.104). In: Proceedings of the 32nd congress of the European committee for treatment and research in multiple sclerosis (ECTRIMS), 2016.

19. Ziemssen $\mathrm{T}$ and Thomas $\mathrm{K}$. Alemtuzumab in the longterm treatment of relapsing-remitting multiple sclerosis: an update on the clinical trial evidence and data from the real world. Ther Adv Neurol Disord 2017; 10(10): 343-359.

20. European Medicines Agency. Alemtuzumab - summary of product characteristics. London: European Medicines Agency, 2013.

21. Agenzia Italiana del Farmaco (AIFA). Determina 23 marzo 2015 (G.U. n82 del 9-4-2015). Rome: AIFA, 2015.

22. CADTH Common Drug Review (CDR). CDEC final recommendation: alemtuzumab. Ottawa, ON, Canada: Canadian Agency for Drugs and Technologies in Health, 2015.

23. National Institute for Health and Care Excellence (NICE). Alemtuzumab for treating relapsing-remitting multiple sclerosis [TA312]. London: NICE, 2014.

24. Agenzia Italiana del Farmaco (AIFA). Scheda Registro Gilenya ${ }^{\circledR}$ (fingolimod). Rome: AIFA, 2015.

25. Agenzia Italiana del Farmaco (AIFA). Scheda Registro Tysabri ${ }^{\circledR}$ (natalizumab). Rome: AIFA, 2016.

26. Agenzia Italiana del Farmaco (AIFA). Scheda Registro Lemtrada ${ }^{\circledR}$ (alemtuzumab). Rome: AIFA, 2016.

27. European Medicines Agency. Daclizumab - summary of product characteristics. London: European Medicines Agency, 2018.

28. Chilcott J, McCabe C, Tappenden P, et al. Modelling the cost effectiveness of interferon beta and glatiramer acetate in the management of multiple sclerosis. Commentary: evaluating disease modifying treatments in multiple sclerosis. $B M J$ 2003; 326(7388): 522.

29. Kurtzke JF. Rating neurologic impairment in multiple sclerosis: an expanded disability status scale (EDSS). Neurology 1983; 33(11): 1444-1452.

30. National Institute for Health Care Excellence (NICE). Single technology appraisal: user guide for company evidence submission template. London: NICE, 2015.

31. Iannazzo S, Santoni L, Saleri C, et al. Analisi di costoefficacia dell'utilizzo di peginterferone beta-1a nel trattamento della sclerosi multipla recidivante remittente in Italia. Farmecon Health Econ Ther Pathways 2016; 17(Supp. 2): 13-36.

32. Lucioni C, Iannazzo S, Maze S, et al. Cost-effectiveness of ponatinib in chronic myeloid leukemia in Italy. Glob Region Health Technol Assess Ital North Eur Span. Epub ahead of print 17 March 2015. DOI: 10.5301/GRHTA.5000189.

33. British Columbia Clinical Genomics Network| Department of Medical Genetics. The BC multiple sclerosis database. Vancouver, BC, Canada: The University of British Columbia, 2015.

34. Palace J, Bregenzer T, Tremlett H, et al. UK multiple sclerosis risk-sharing scheme: a new natural history dataset and an improved Markov model. BMJ Open 2014; 4(1): e004073.

35. Sanofi Genzyme. [Data on file] - pooled CARE I and CARE II patient population. Cambridge, MA: Sanofi Genzyme, 2016.

36. Orme M, Kerrigan J, Tyas D, et al. The effect of disease, functional status, and relapses on the utility of people with multiple sclerosis in the UK. Value Health 2007; 10(1): 54-60.

37. Institute for Clinical and Economic Review (ICER). Disease-modifying therapies for relapsing-remitting and primary-progressive multiple sclerosis: effectiveness and 
value. Final Evidence Report, Institute for Clinical and Economic Review, Boston, MA, 6 March 2017.

38. Held U, Heigenhauser L, Shang C, et al. Predictors of relapse rate in MS clinical trials. Neurology 2005; 65(11): 1769-1773.

39. Patzold T, Schwengelbeck M, Ossege LM, et al. Changes of the MS functional composite and EDSS during and after treatment of relapses with methylprednisolone in patients with multiple sclerosis. Acta Neurol Scand 2002; 105(3): 164-168.

40. Pokorski RJ. Long-term survival experience of patients with multiple sclerosis. J Insur Med 1997; 29(2): 101-106.

41. Tappenden P, McCabe C, Chilcott J, et al. Cost-effectiveness of disease-modifying therapies in the management of multiple sclerosis for the Medicare population. Value Health 2009; 12(5): 657-665.

42. O'Connor P, Wolinsky JS, Confavreux C, et al. Randomized trial of oral teriflunomide for relapsing multiple sclerosis. $N$ Engl J Med 2011; 365(14): 1293-1303.

43. Boye KS, Matza LS, Walter $\mathrm{KN}$, et al. Utilities and disutilities for attributes of injectable treatments for type 2 diabetes. Eur J Health Econ 2011; 12(3): 219-230.

44. National Institute for Health and Care Excellence (NICE). Natalizumab for the treatment of adults with highly active relapsing-remitting multiple sclerosis [TA 127]. London: NICE, 2006.

45. Lloyd A, Nafees B, Narewska J, et al. Health state utilities for metastatic breast cancer. $\mathrm{Br} J$ Cancer 2006; 95(6): 683-690.

46. Sander B, Hayden FG, Gyldmark M, et al. Post-exposure influenza prophylaxis with oseltamivir: cost effectiveness and cost utility in families in the UK. Pharmacoeconomics 2006; 24(4): 373-386.

47. Razvi S, Ingoe LE, McMillan CV, et al. Health status in patients with sub-clinical hypothyroidism. Eur J Endocrinol 2005; 152(5): 713-717.

48. Van Hoek AJ, Underwood A, Jit M, et al. The impact of pandemic influenza H1N1 on health-related quality of life: a prospective population-based study. PLoS ONE 2011; 6(3): e17030.

49. Polman CH, O'Connor PW, Havrdova E, et al. A randomized, placebo-controlled trial of natalizumab for relapsing multiple sclerosis. $N$ Engl J Med 2006; 354(9): 899-910.

50. Sullivan PW and Ghushchyan V. Preference-based EQ-5D index scores for chronic conditions in the United States. Med Decis Making 2006; 26(4): 410-420.

51. Nafees B, Lloyd AJ, Dewilde S, et al. Health state utilities in non-small cell lung cancer: an international study. Asia Pac J Clin Oncol 2017; 13(5): e195-e203.

52. National Institute for Health and Care Excellence (NICE). Fingolimod for the treatment of highly active relapsingremitting multiple sclerosis [TA254]. London: NICE, 2012.

53. Kappos L, Radue EW, O'Connor P, et al. A placebocontrolled trial of oral fingolimod in relapsing multiple sclerosis. N Engl J Med 2010; 362(5): 387-401.

54. Randomised double-blind placebo-controlled study of interferon beta-1a in relapsing/remitting multiple sclerosis. PRISMS (prevention of relapses and disability by interferon beta-1a subcutaneously in multiple sclerosis) study group. Lancet 1998; 352(9139): 1498-1504.
55. Secondary Progressive Efficacy Clinical Trial of Recombinant Interferon-Beta-1a in MSSG. Randomized controlled trial of interferon- beta-1a in secondary progressive MS: clinical results. Neurology 2001; 56(11): 1496-1504.

56. Ebers G, Rice G, Lesaix J, et al. Randomised double-blind placebo-controlled study of interferon B-1a in relapsing/ remitting multiple sclerosis. Lancet Neurol 1998; 352: 1498-1504.

57. Twyman CL, Montalban X, Arnold DL, et al. Relapse outcomes with alemtuzumab vs. Ifnb-1a in active relapsingremitting multiple sclerosis patients who experienced disease activity while on prior therapy (CARE-MS II) (P07.098). The 65th Annual Meeting of the American Academy of Neurology San Diego, California, USA, 16-23 March, 2013.

58. Haas J, Hartung H, von Rosenstiel Peal, et al. Gilenya reduces the number of severe relapses in patients with relapsing multiple sclerosis: results from Phase III TRANSFORMS and FREEDOMS studies. Lisbon: ENS, 2011.

59. A cura del Gruppo Multidisciplinare sui Farmaci Neurologici RE-R. Linee guida terapeutiche/10: 'Farmaci per la cura della sclerosimultipla con particolare riferimento a dimetilfumarato, teriflunomide, alemtuzumab' (dicembre 2015), http://salute. regione.emilia-romagna.it/documentazione/ptr/elaborati/271linee-guida-sclerosi-multipla-2018/view

60. Ministero della Salute. Tariffe nazionali prestazioni di assistenza ospedaliera per acuti (sistema DRG) e tariffario ambulatoriale Dec. 18 ottobre 2012 G.U. n.23 del 28-012013. Rome: Ministero della Salute, 2013.

61. National Institute for Health and Care Excellence (NICE). Guide to the methods of technology appraisal. London: NICE, 2013.

62. Agenzia Italiana del Farmaco (AIFA). Nota 65 (G.U. $n 65$ di 18-3-2016). Rome: AIFA, 2016.

63. Briggs A, Schulper M and Claxton K. Decision modelling for health economic evaluation. Oxford: Oxford University Press, 2011

64. Fattore G. Proposta di linee guida per la valutazione economica degli interventi sanitari in Italia. Pharmacoecon Italian Res Article 2009; 11(2): 83-93.

65. Furneri G, Santoni L, Marchesi C, et al. Cost-effectiveness analysis of delayed-release dimethyl-fumarate in the treatment of relapsing-remitting multiple sclerosis in Italy. Value Health 2015; 18(7): A697.

66. Furneri G, Santoni L, Ricella C, et al. Cost-effectiveness of escalating to natalizumab or switching among immunomodulators in relapsing-remitting multiple sclerosis in Italy. Value Health 2015; 18(7): A695.

67. Iannazzo S, Santoni L, Saleri C, et al. Cost-effectiveness analysis of peginterferon beta-1a in Italian relapsing remitting multiple sclerosis management. Value Health 2015; 18(7): A758.

68. Dashputre AA, Kamal KM and Pawar G. Cost-effectiveness of peginterferon beta-1a and alemtuzumab in relapsingremitting multiple sclerosis. J Manag Care Spec Pharm 2017; 23(6): 666-676.

69. Montgomery SM, Kusel J, Nicholas R, et al. Costs and effectiveness of fingolimod versus alemtuzumab in the treatment of highly active relapsing-remitting multiple sclerosis in the UK: re-treatment, discount, and disutility. $J$ Med Econ 2017; 20(9): 962-973. 